\title{
Goitre by Using Scintigraphy and Biopsy in Sudan
}

\author{
Amin A. Elzaki ${ }^{1,2}$, Hamid Osman ${ }^{2}$ \\ ${ }^{1}$ Alzaiem Alazhari University, College of Radiological Sciences and Medical Imaging, Sudan \\ ${ }^{2}$ Taif University, College of Applied Medical Science, Radiological Science Department, KSA
}

Corresponding Author Amin A. E. Elzaki

Mobile:

+966533821879

Email:

Aminzaki2000@yahoo. $\underline{\text { com }}$

Received :24 / 1/2012

Accepted after

revision: $20 / 2 / 2012$

Key words:

Endemic Goitre;

Scintigraphy; Biopsy;

Nodular goitre
Background and study aim: Goitre has been recognized in Sudan as a public health problem since the 1950's. Nationwide surveys on goitre were launched and various approaches in the quest for a solution to the problem were applied. Still, the number of goitrous individuals continues to grow each year. This article sheds lights and reiterates the frequency of goitre in Sudanese in the basis of scintigraphy and biopsy. The statistical findings should be especially useful to professionals in endemic medicine and endocrinology.

Patients and methods: The study was conducted at the Radiation and Isotope Center (RICK), Khartoum . A total of 400 patients received $2 \mathrm{mCi}$ of $\mathrm{Tc} 99 \mathrm{~m}$ Pertechnetate intravenously. Imaging was performed using a Nucline gamma camera computer system with general purpose parallel hole collimator. Biopsy was carried out by Fine Needle Aspiration Biopsy (FNAB) with the guidance of ultrasonography.
Results: Goitre was more among females $(88.8 \%)$ as compared to males $(11.2 \%)$ with a female: male ratio of $8: 1$. Goitre increased in the age group 20-40 with an average age of 35 years. Scintigraphy revealed diffuse goitre in $57.5 \%$, multi nodular goitre in $37.5 \%$ and a single (solitary) thyroid nodule in $5 \%$ of the sample studied. Toxic goitre was reported in $4 \%$ of the patients while the rest were diagnosed as non-toxic goitre . The biopsy results showed that $8 \%$ of nodular goitres were malignant and the rest had cystic or degenerative changes only.

Conclusion: The study suggests that goitre in its major kinds, diffuse or nodular have the same frequency scintigraphically. Thyroid malignancy within nodular goitre remains in the minimum level. The goitre sill remains a major public health issue in Sudan and implementing iodine prophylaxis programs must be more activated.

\section{INTRODUCTION}

Goitre is an enlarged thyroid gland [1]. Goitre is a major manifestation of iodine deficiency, it is a world-wide problem $\quad[2,3,4,5,6,7]$. Iodine deficiency not only causes goitre, the obvious sign of inadequate iodine intake, but may also result in irreversible brain damage in the fetus and infant, and retarded the psychomotor development in the child [8]. Goitre is classified anatomically into: diffuse and nodular (single "solitary" nodule and multinodular goitre), which is easy to detect sonographically by the outer shape. Also goiter can be divided physiologically into simple and toxic which can be detected by scintigraphy. The diffuse or nodular nature of goitre can be diagnosed by clinical examination, as well as by using scintigraphy and sonography $[3,9,10,11,12,13]$. Nuclear medicine imaging of thyroid provides useful information about the shape, size and site of thyroid tissue, the function of thyroid nodule, and functioning thyroid tissue in patients with thyroid carcinoma. Either iodine-123 ( $\left.\mathrm{I}^{123}\right)$ or technetium-99m $\left(\mathrm{Tc}^{99 \mathrm{~m}}\right)$ may be used [14].

Goitre has been recognized in Sudan as a public health problem since the 1950's [15]. This study was aimed on the scintigraphic and biopsy examinations of frequency of goitre in Sudanese population. 


\section{PATIENTS AND METHODS}

The primary data and the family history for a total of 400 patients referred in to the department of Nuclear Medicine at the Radiation and Isotope Center( RICK), Khartoum were reported. Kind of goitre was studied by clinical examination to the neck and the classification of goitre was estimated.

Sample was separated into four groups: bellow $20,20-40,41-60$, and those above the age of 60 years.

Scintigraphic examination for the sample involved the intra-venous injection of $2 \mathrm{mCi}$ of Tc ${ }^{99 \mathrm{~m}}$ pertechnetate, followed by 15 minutes $(150 \mathrm{~K}$ counts) at the neck area using a general purpose parallel holes collimator and a Nucline gamma camera computer system, with the patient in a supine position. The examinations were sufficient to determine the kinds of goitre in the patients.

Fine Needle Aspiration Biopsy (FNAB) for the nodular goitres by a plastic disposable syringe and a glass slide was used to carry out the laboratory test. The aspiration was used with the guidance of a $7.5 \mathrm{MHz}$ linear probe transducer attached to a General Electric (GE) medial ultrasound system.

\section{RESULTS}

Goitre was found to affect females in the reproductive age group less than 40 years, with a female to male ratio of $8: 1$. The average age was 35 years. The peak was among females between 20-40 years of age presenting the percent of $54.3 \%$.

The majority of patients were from Khartoum state $(35.5 \%), \mathrm{Al}$ Gezera and Central Sudan (29\%), Kordofan and Darfur at Western Sudan (24.2\%), Northern Sudan (7.8\%), Southern Sudan (2.0\%) and Eastern Sudan (1.5\%) (Figure 1).

Clinically, 166 (42\%) patients showed moderate goitre, large goitres in $81(20 \%)$, small goitres in $95(24 \%)$ and huge goitres in $29(7 \%)$ (Figure 2).

Scintigraphy revealed diffuse goitre in $57.5 \%$, multinodular goiter in $37.5 \%$ and a single "solitary" thyroid nodule in 5\% of the sample studied. Toxic goitre (Figure 3) was reported in $4 \%$ of the patients while the rest were diagnosed as non-toxic goitre (Figure 4).

Biopsy revealed that $8 \%$ of the histopathological findings of the nodular goitre were malignancies, whereas $92 \%$ were benign cytologic findings. Among the malignancies $21 \%$ were follicular adenocarcnioma and $79 \%$ were lymphoma. Histopathological results of benign nodules included 30\% benign nodular goitre and $70 \%$ were nodular goitre with cystic or degenerative changes. 


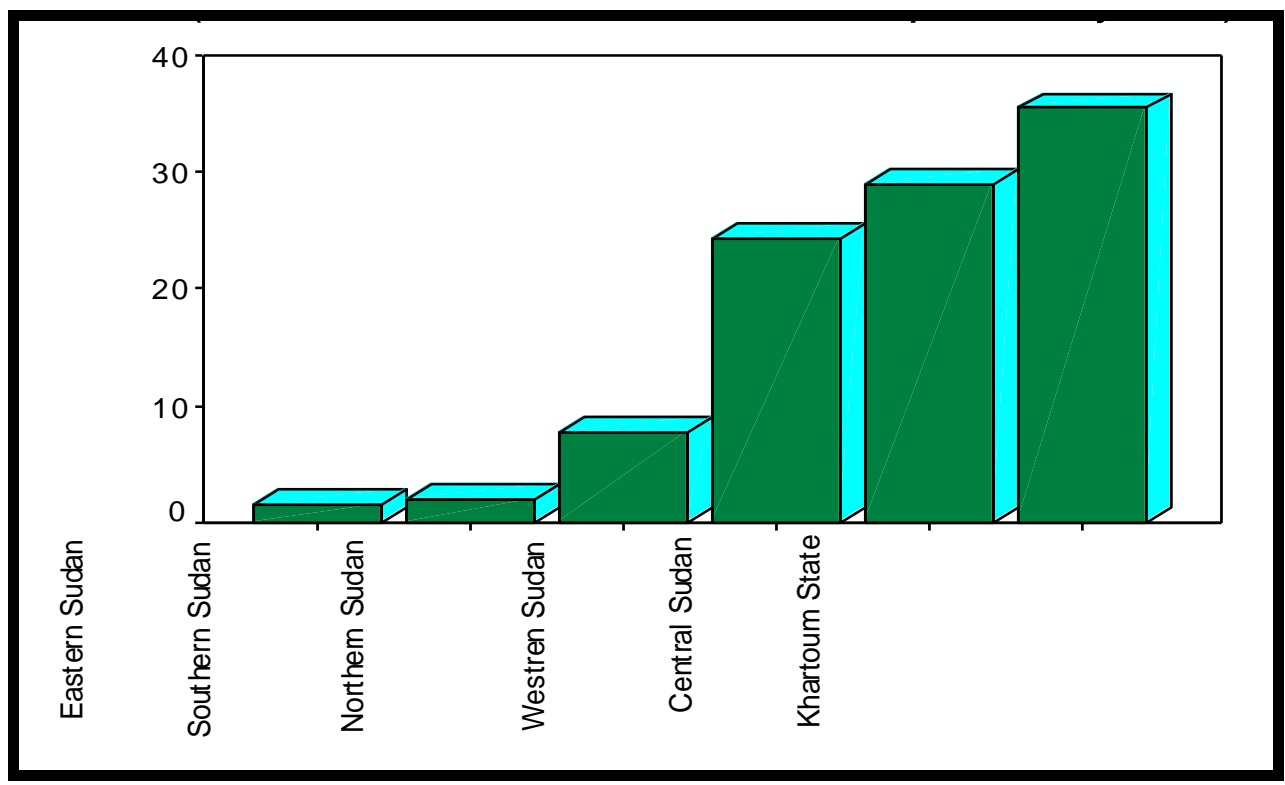

Figure 1: Geographical area

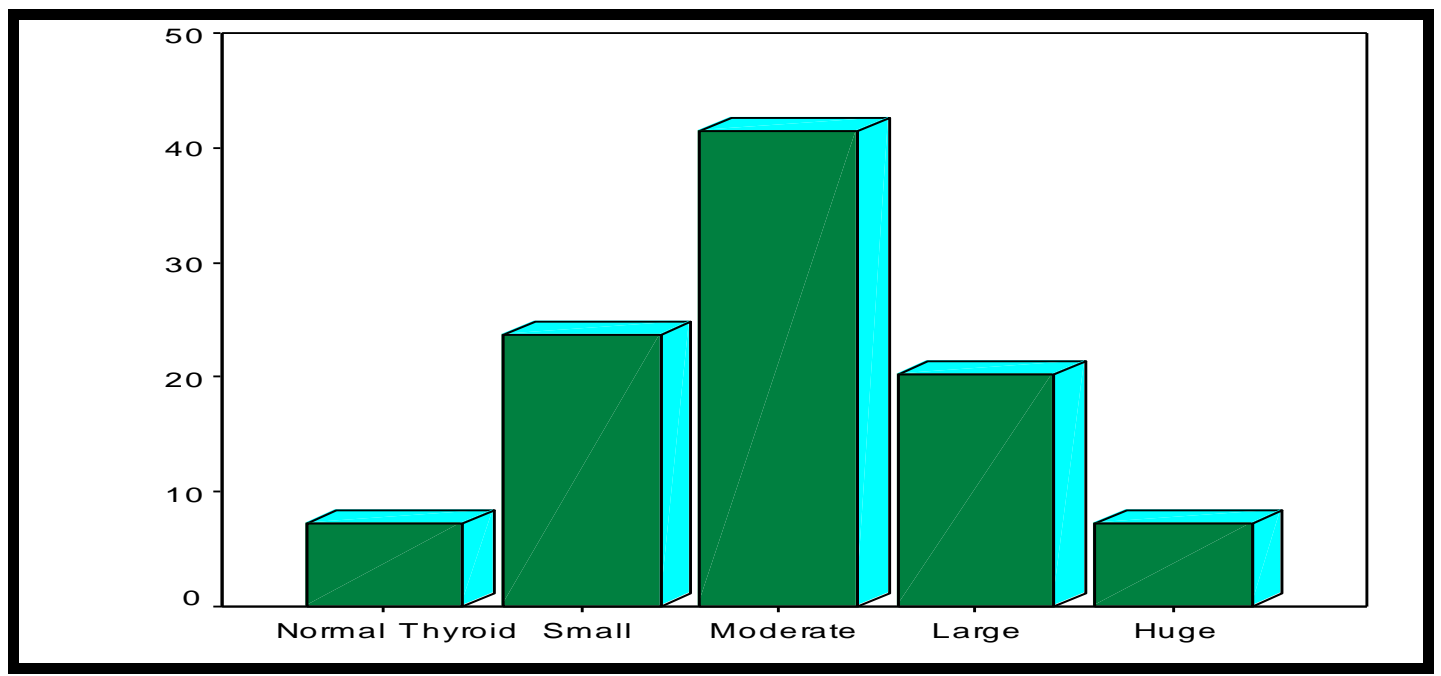

Figure 2: Clinical classification of goiter

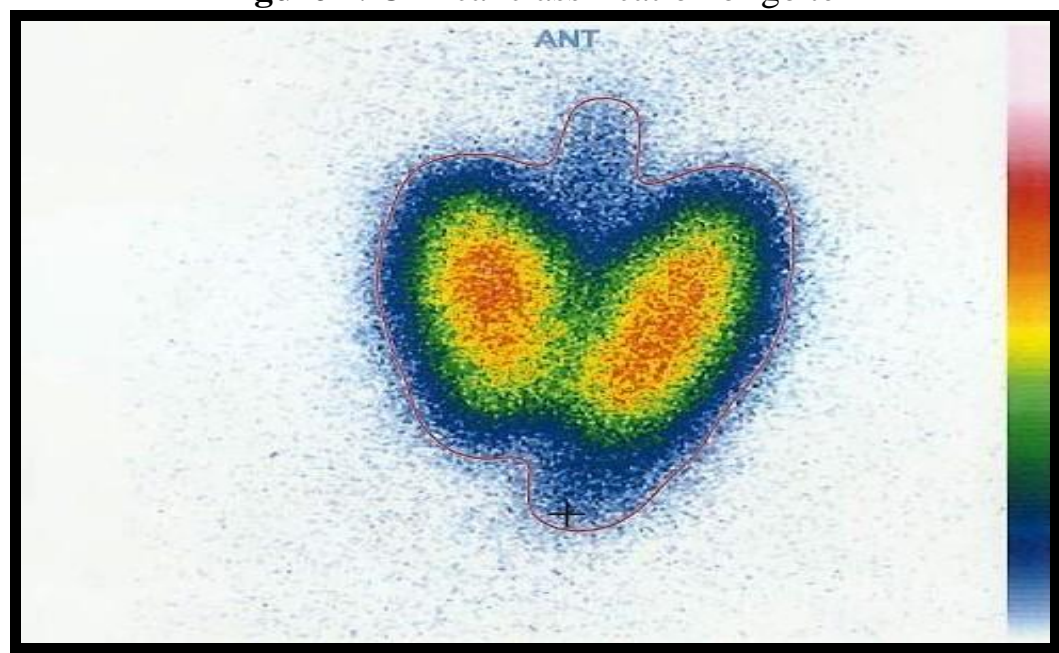

Figure 3: Scintigraphic features of diffuse toxic goitre. The static Spot of the anterior neck was acquired $15 \mathrm{~min}$. following administration of $2 \mathrm{mCi}$ of $\mathrm{Tc}^{99 \mathrm{~m}}$. The thyroid gland is enlarged with no suprasternal extension. Intense homogenous radiotracer uptake portrayed all over the gland with deprivation of extra thyroid tissue from their normal tracer share denoting the activity of the gland to the tracer uptake, with the appearance of pyramidal lobe. 


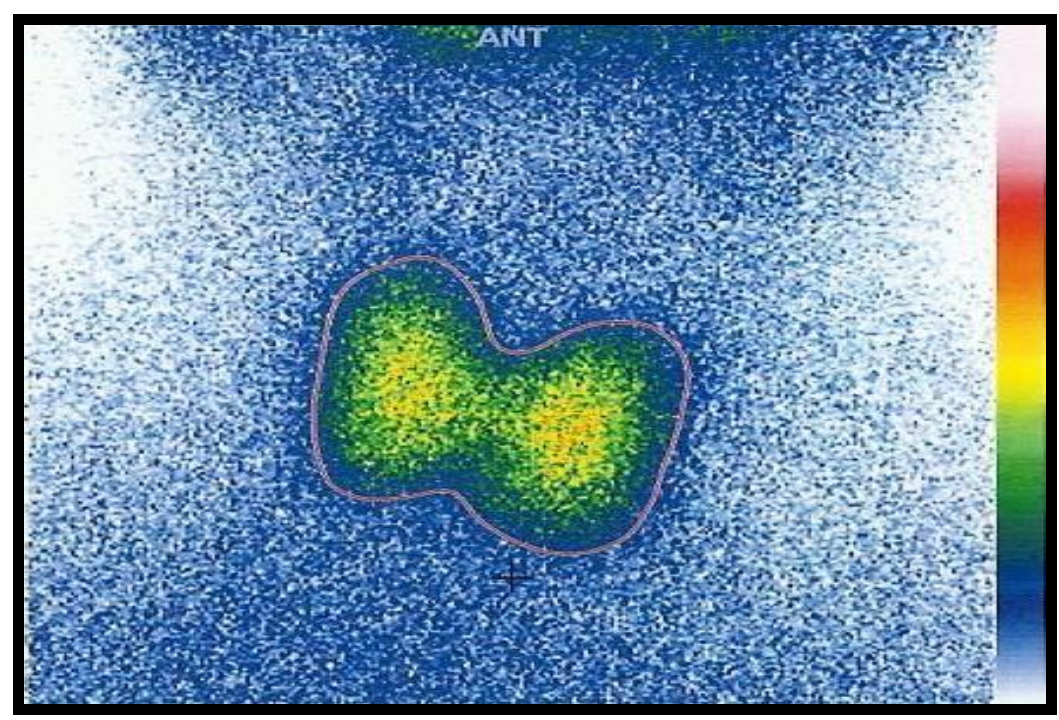

Figure 4: Scintigraphic features of diffuse non toxic goitre. The static spot view of anterior neck was acquired $15 \mathrm{~min}$. following administration of $2 \mathrm{mCi}$ of $\mathrm{Tc}^{99 \mathrm{~m}}$. The thyroid gland is enlarged with no evidence of retrosternal extension. Homogenous radiotracer uptake portrayed all over the gland with normal extra thyroidal tissue tracer uptake.

\section{DISCUSSION}

Goitre has been sufficiently investigated in many of its manifestation, world-wide. Williams determined that goitre is 7 to 9 times more common in women than in men [16]. The prevalence of goitre in women has been supported in the studies done in Turkey $[5,17,18,19,20]$. However, the female/male ratio varies among the researchers: 4.5 was reported by Kologlu [5]; 3.2 by Urgancioglu[18] ; 4.0 by Karpuzoglu [19]; 5.2 by Yilmaz [20]. In Sudan also, the prevalence of goitre in women has been supported by Mohamed et al, study [21]. Mohamed and his colleagues study showed the frequency of $81 \%$ were females. The current study result of 8.1 and $88.8 \%$ is within Williams and Mohamed range of values respectively. Still women suffer from goitre more than men in Sudanese patients.

Many of the researchers point out that the incidence of goitre increases during puberty, and that the upward trend continues thereon, especially in women, becoming most frequent in both sexes in the age group 20-40 [5,17,22,23].

The current study has shown that the frequency of goitre was higher in women, and that for both sexes goitre was highest, in the age group of 2040 while Erkan reported that the frequency of goitre is highest in the age group of 15-30 [24].

Greig et al. reported a frequency of goitre of $12.2 \%$ in Khartoum region. $\mathrm{He}$ considered Khartoum to be an endemic area according to the
World Health Organization (WHO) committee which regarded any area in which the frequency of goitre exceeding $10 \%$ to be considered as an endemic area [25].

Geographical area distribution in this study points to where the patient used to live within the past 20 years permanently. The majority of our patients $(35.5 \%)$ were from Khartoum State. Those from Gazira and Central region constituted $29 \%$ of our patients. Kordofan and Darfur at western Sudan, being known endemic areas of goitre were presented by $24.2 \%$ of our patients.

Also the current results confirmed diffuse goitre in $57.5 \%$, multinodular goiter in $37.5 \%$ and a single "solitary" thyroid nodule in $5 \%$ of the sample studied. This results near to matches with Mohamed's study who revealed that $58 \%$ of patients had nodular goitre while the rest had diffuse goitre [21].

Malignancies with the nodular goitre types was only $8 \%$ of the histopathological findings. This result is near to Mohamed's study from Sudan who revealed that $14 \%$ of the nodular goitre showed a type of malignancy[21].Also, Kapur from India reported a frequency of $10 \%$ malignancy among patients with solitary thyroid nodule [26].

\section{CONCLUSION}

Goitre still remains a major problem in Sudan. The geographic isolation and the socioeconomic, cultural, and political factors in Sudan contribute 
to the technical difficulty in implementing iodine prophylaxis programs. Scintigraphy is an important method to identify the morphology of the thyroid gland as well as monitoring and curing the disease.

\section{Funding:Non}

\section{Conflicts of interest;Non.}

Ethical considerations: Special consideration was given to the right to confidentiality and anonymity of all patients. Anonymity was achieved by using numbers for each patient that will provide link between the information collected and the participants. In addition confidentiality was ensured by making the collected data accessible only to the researchers. The right to equality was ensured by giving each patient the same number and type of scintigraphy and laboratory procedures.

Justice and human dignity was observed by treating selected patients equally when offering them an opportunity to participate in the study. The patients are free to decide whether to participate or not. The patient was given informed consent that will be signed after explanation of the purpose, possible outcomes of the study and conditions applying to their participation. Permission to conduct the study was obtained from the hospitals directors as well as the superintendent radiographer in the nuclear medicine department at RICK.

\section{ACKNOWLEDGEMENT}

We would like to express our grateful thanks to Prof/ Dr.Ahmed Sulman Ahmed and Dr. Siddik M. Mustafa, for their advice, encouragement, and illuminating criticisms and for many helpful suggestions regarding the manuscript. We would like to thank the head department of Nuclear Medicine at RICK Dr. Manal Elgak for her cosupervision and supplying the samples used in the study. We would also like to acknowledge the assistance of the technical staff of the Department of Nuclear Medicine at RICK. We are also extending our gratitude to Dr. Hamid Humaida the head of the Statistical Department, Faculty of Sciences, Sudan University of Sciences and Technology (SUST) who conducted the statistical analysis.

\section{REFERENCES}

1. James RM. Goitre. Medscape reference. 2007. www.patient.co.uk/health/goitre- (Thyroid swelling)- html (Accessed 12 December 2011).

2. Berkow R, Talbott JH. Goitre. In the Merck Manual, $13^{\text {th }}$ ed., Merck Sharp and Dohme Research Labs ;Rahway 1977 ;1264

3. Bilir N. The problem of simple goitre in Turkey. Toplum ve Hekim 1986 ;41:23-27

4. Hershman JM, Due DT, Sharp B, My I, Kent JR, Binh LE, et al. Endemic Goitre in Vietnam. $J$ Clin Endoc Metab 1983 ;57:243-249

5. Kologlu S. Endemic Goitre in Turkey. University of Istanbul, Cerrahpasa Journal of Medical Faculty, Emek Matbaacilik 1984; 1-64

6. Roti E, Gardini E, D'amato L, Salvi M, Robuschi G, Manfredi A, et al. Goitre Size and Thyroid Function in an endemic Goitre Area in Northern Italy. J Clin Endoc Metab 1986 ;63:558-562

7. Urgancioglu I, Hatemi H, Kökoglu E, Guven Y, Sur N, Yilmaz O. Iodine Determination in Drinking Water Samples of Turkey; In Relation to the Endemic Goitre Problem. University of Istanbul, Cerrahpaşa Journal of Medical Faculty, Istanbul 1982;3:1-16

8. Pharoah POD, Buttfield IH, Hetzel BS. The effect of iodine prophylaxis on the incidence of endemic cretinism', In: Human Development and the Thyroid Gland, Stanbury JB, Kroc RL (eds). Plenum Publishing Corp ;New York 1972 :201

9. Harbert J. The Thyroid. ÝIn Harbert J, Rocha AFG (Eds.), Textbook of Nuclear Medicine, $2^{\text {nd }}$ ed., Philadelphia, Lea and Febiger 1984 ;3-52

10. Ikekubo $\mathrm{K}$, Higa $\mathrm{T}$, Hirasa $\mathrm{M}$, Ishihara $\mathrm{T}$, Waseda N, Mori T. Evaluation of Radionuclide Imaging and Echography in the Diagnosis of Thyroid nodules. Clin Nucl Med $1986 ; 11: 145$

11. Katz JF, Kane RA, Reyes J, Clarke MP, Hill TC. Thyroid Nodules; Sonographic-Pathologic Correlation. Radiology 1984 ;151:741-745

12. Raikor UR, Sharma SM. Ultrasound and Radionuclide Imaging in Management of Thyroid Nodules. Presented at the International Symposium on Nuclear Medicine and Related Medical Applications of Nuclear Techniques in Developing Countries organized by IAEA and WHO, Vienna 1986.

13. Simeone J, Mueller PR, Sonnenberg EV. Sonograhy of Thyroid Gland. In Leopold GR (Ed.), Ultrasound in Breast and Endocrine Disease, $1^{\text {st }}$ edition, New York, Churchill Livingstone Inc, 1984 ;83-92

14. Donald R. Bernier, Paul E. Christian, James K. Langa. Nuclear Medicine Technology and Techniques, $4^{\text {th }}$ ed., Mosby 1971. 
15. Woodman H. Endemic Goitre in Central Africa. East. Afr. Med J 1952 ;29(6), 217-28

16. Williams RH. Textbook of Endocrinology. $4^{\text {th }}$ ed., WB Saunders Co, London 1968 ;259-260.

17. Köksal O. Nutrition in Turkey. In Köksal O (Ed), Nutrition, Health and Food Consumption Research in Turkey for 1974, Aydin Matbaasi, Ankara 1977.

18. Urgancioglu I, Hatemi H, Yenici O, Guven Y, Sur N, Yilmaz O et al. Endemic Goitre in Turkey. Istanbul, Ornek Matbaasi, 1988 ;8-39.

19. Karpuzoglu T, Akaydin M, Emek K. Surgical Approach in the Treatment of Thyroid patients at Akdeniz University Hospital, Presented at the $4^{\text {th }}$ Balkan Congress of Endocrinology, Izmir 1985.

20. Yilmaz M, Sencer E, Yenerman M, Orhan Y, Molvalilar S, Kaya M. Diagnostic Value of Fine Needle Aspiration Biopsy in Nodular Goitre, Presented at the $4^{\text {th }}$ Balkan Congress of Endocrinology, Izmir 1985.
21. Mohamed Y, Sulieman A, Osman H, Adam M, Eltom K. Evaluation of thyroid nodules, SMM $2011 ; 6(3): 221-227$

22. Clements FW. Endemic goitre, nutrition and preventive medicine. WHO Monograph Series, $1976 ; 62: 83-93$.

23. Eser S. Nutrition and goitre in Northern Anatolia. Journal of Istanbul University Medical School, 1966 ;2:578-582.

24. Erkan I, Radife A, Guner E, Gulsern A, Hulusi O, Asim A. The incidence of nodule in patients with goitre. Journal of Islamic Academy of Science $1990 ; 3: 3,221-224$

25. Greig WR, Gray HW, McGirr EM, Kambal A, Rahman IA. Investigation of Endemic Goitre in Sudan. BJS $1970 ; 57(1): 11-16$

26. Kapur, M.M, Senda, AK, Kumar. A. The Cold Solitary Thyroid Nodule, Indian J. cancer 1980 ;179, 172-175. 